\title{
Royal Patronage of Illicit Print: Catherine of Braganza and Catholic Books in Late Seventeenth-Century London
}

\author{
Chelsea Reutcke
}

In 1662, the English Parliament passed An Act for preventing the frequent Abuses in printing. ${ }^{1}$ Among its many provisions, the act prohibited the printing or importation of any texts opposed to the Church of England, including books with Catholic content. Proscribed works were confiscated and either destroyed or 'damasked' (i.e., over-printed) for waste paper, while the printers and booksellers faced fines, confiscation of equipment and imprisonment. ${ }^{2}$ That same year, Catherine of Braganza, newly arrived in London, appointed Theodore Sadler as her bookseller-in-ordinary, instructing him to procure for her a list of Catholic devotional books. ${ }^{3}$ He submitted receipts to the exchequer for seven Roman breviaries, two psalters of Beata Maria hymns, a Roman missal, fifty 'bookes for a night hearing of mass' and an Iberian rubric. ${ }^{4}$ Even more books arrived from France. ${ }^{5}$ These orders served to set up Catherine's Catholic chapel, which had been promised to her in her marriage contract to Charles II. ${ }^{6}$ Together with books ordered by Henrietta Maria, the Queen Mother, a significant number of Catholic books entered into these sanctioned Catholic spaces of London. ${ }^{7}$

1 'Charles II, 1662: An Act for preventing the frequent Abuses in printing seditious treasonable and unlicensed Bookes and Pamphlets and for regulating of Printing and Printing Presses', in John Raithby (ed.), Statutes of the Realm (11 vols., s.l.: Great Britain Record Commission, 1819), V. 428-435. Hereafter 14 Car. II. c. 33 .

2 Charles Robert Rivington, The Records of the Worshipful Company of Stationers (Westminster: Nicholas and Sons, 1883), pp. 33-41.

3 Donald F. McKenzie and Maureen Bell, A Chronology and Calendar of Documents Relating to the London Book Trade 1641-1700 (3 vols., Oxford: Oxford University Press, 2005), I. 1662.5? [sic], hereafter $C C L B T$ [all references will be presented as dates: dd.mm.yyyy].

4 The National Archives, State Papers [hereafter SP] 29/55 f.46; Peter Leech, 'Musicians in the Catholic Chapel of Catherine of Braganza, 1662-1692', Early Music, 29 (2001), p. 573.

5 CCLBT, I. 21.10.1662; SP 29/67 f.131; SP 29/67 f.133.

6 L.M.E. Shaw, The Anglo-Portuguese Alliance and the English Merchants in Portugal 1654-1810 (Aldershot: Ashgate, 1998), p. 175 .

$7 \quad C C L B T$, vol. I, 20.11.1662. 
The new queen occupied a grey area with regard to the laws governing religion in Restoration England, including those concerning print. Unlike other Catholics in England, she could legitimately order Catholic books for her chapel and private use, just as she had done in the spring of 1662 . Yet, on at least two occasions, the activities of Catherine's booksellers linked her to networks of illicit Catholic printing. She also directly intervened to protect an unlicensed printer from prosecution. Moreover, by the mid-1670s, her residence at Somerset House had become the centre around which the illicit Catholic book trade organized itself. Catherine operated as the heart of a grand network of Catholic print. She leveraged the power afforded her by her status and her marriage treaty to foster and protect the English Catholic population of London through print.

While much scholarly work has been devoted to the relationship between the state and the London book trade, it has focused on Charles II's censorship activities, particularly the suppression of nonconformist and Whig print. ${ }^{8}$ In contrast, his queen's activities in relation to the book trade have not been given their full due. ${ }^{9}$ This parallels the general historical treatment of Catherine of Braganza as both passive and ineffectual, particularly with regard to her barrenness. However, Adam Morton has qualified this view by arguing that, while her role as a political agent was less overt than that of Henrietta Maria, it was in no way non-existent. Both Morton and Edward Corp seek to give Catherine agency by emphasizing her promotion of a 'Baroque Catholic culture.' ${ }^{10}$ Other

8 Michael Treadwell, 'The Stationers and the Printing Acts at the End of the Seventeenth Century', in Donald F. McKenzie, John Barnard, and Maureen Bell (eds.), The Cambridge History of the Book in Britain (7 vols., Cambridge: Cambridge University Press, 2002), IV, pp. 755-776; J. Walker, 'The Censorship of the Press during the Reign of Charles II', History, 35 (1950), pp. 219-238; Philip Hamburger, 'The Development of the Law of Seditious Libel and the Control of the Press', Stanford Law Review, 37 (1985), pp. 661-765; Anne Dunan-Page and Beth Lynch (eds.), Roger L'Estrange and the making of Restoration culture (Burlington, VT: Ashgate, 2008); Maureen Bell, 'Offensive Behaviour in the English Book Trade 1641-170o', in Robin Myers, Michael Harris and Giles Mandelbrote (eds.), Against the Law: Crime, Sharp Practice and the Control of Print (New Castle/London: Oak Knoll Press \& The British Library, 2004), pp. 61-79.

9 One exception is Dorothy Kim, 'Female Readers, Passion Devotion, and the History of MS Royal 17 A. Xxvii', Journal of the Early Book Society for the Study of Manuscripts and Printing History, 15 (2012), pp. 188-189.

10 Adam Morton, 'Sanctity and Suspicion: Catholicism, conspiracy and the representation of Henrietta Maria of France and Catherine of Braganza, Queens of Britain', in Helen Watanabe-O'Kelly and Adam Morton (eds.), Queens Consort, Cultural Transfer and European Politics, c.1500-180o (London: Routledge, 2016), pp. 177-178; Edward Corp, 'Catherine of Braganza and Cultural Politics', in Clarissa Campbell Orr (ed.), Queenship 
studies have looked at how she attempted to assert her identity through her chapel music."1

While these arguments often focus on high court culture, this article looks instead towards the wider population. After all, recusants of all ranks attended London's Catholic chapels. ${ }^{12}$ Catherine had been sent to England with the understanding that she should serve as the 'focal point' for all English Catholics, not just those in the court. ${ }^{13}$ For the majority of this Catholic population, recusant and church papist alike, their faith required breaking the law. ${ }^{14}$ Therefore, the queen's role in illegally providing for this illicit population must be considered. Catherine's goals and her willingness to trespass against the statutes approved by her husband emerge from this analysis of the power relationship between the queen and print.

\section{Catherine the Catholic Patroness}

Contemporaries recognized the queen's ability to provide protection and patronage to those producing Catholic books. In 1663, following her arrival in England, the Benedictines Arthur Crowther and Thomas Vincent released a second abridged edition of their handbook for the Arch-Confraternity of the Rosary entitled Jesus, Maria, Joseph: or, The devout pilgrim of the ever blessed Virgin Mary. ${ }^{15}$ Their confraternity had resided in London since the $1650 \mathrm{os}$, eventually settling at Cardigan House in Lincoln's Inn Fields. ${ }^{16}$ Crowther and

in Britain 1660-1837: Royal Patronage, Court Culture and Dynastic Politics (Manchester: Manchester University Press, 2002), pp. 53-73.

11 Leech, 'Musicians in the Catholic Chapel of Catherine of Braganza', pp. 570-587.

12 James Miller, Popery and Politics in England, 1660-1688 (Cambridge: Cambridge University Press, 1973), pp. 22-23.

13 Shaw, Anglo-Portuguese Alliance, p. 175, 183 note 19. According to Shaw, the Biblioteca Ajuda in Lisbon contains several letters to this effect.

14 For more on church papists, see Alexandra Walsham, Church Papists: Catholicism, Conformity and Confessional Polemic in early modern England (Woodbridge: Boydell \& Brewster, 1999).

15 Arthur Crowther and Thomas Vincent, Jesus, Maria, Joseph: or, The devout pilgrim of the ever blessed Virgin Mary. In his holy exercises upon the sacred mysteries of Jesus, Maria, Joseph. With the charitable association for the relief of the souls departed. Published for the benefit of the pious Rosarists, by A.C. and T.V. religious monks, of the Holy Order of S. Bennet (Amsterdam: s.n., 1663), English Short Title Catalogue (hereafter ESTC) R213436.

16 Anne Dillon, "To seek out some Comforts and Companions of his own kind and condition': The Benedictine Rosary Confraternity and Chapel of Cardigan House, London', in Lowell Gallagher (ed.), Redrawing the Map of Early Modern English Catholicism (Toronto: University of Toronto Press, 2012), p. 274. 
Vincent dedicated the book to 'her most sacred Majesty, Catherina, Queen of Great Britain', and the frontispiece featured a large portrait of her alongside her coat of arms. ${ }^{17}$ The book was printed in Amsterdam and then smuggled into England. ${ }^{18}$ In the dedication, the Benedictines stated, 'we conceive our selves to stand more engaged to your Majesty, than many other' and that 'our very subsistence depends (after God) ... Upon your Patronage and Protection.' ${ }^{19}$ Crowther and Vincent felt the arrival of a new Catholic queen had altered their fortunes, and their book was an attempt to flatter Catherine and win her approval.

Dedications formed part of the language of expectation by the English Catholic populations at home and overseas, in which authors laid out their vision of the new queen. Thomas Hawkins had used a similar tactic when he dedicated his translation of Nicolas Caussin's The Holy Court in 1626 to Charles I's new bride, Henrietta Maria. ${ }^{20}$ They had cause to hope, as Catherine herself had a fondness for rosarists and upheld the veneration of Mary. In 1669 Catherine established her own confraternity of the rosary under the control of the Dominicans at the Chapel Royal of St James's Palace. ${ }^{21}$ That same year a pamphlet appeared in London detailing the method of saying the rosary 'as it was said in Her Majesties chappel at St James.'22 Although Catherine's confraternity followed the Dominican method, she still had ties to Crowther's Benedictine house. She knew Crowther, as he had formed part of the

17 Crowther and Vincent, Jesus, Maria, Joseph.

18 There has been some debate as to whether or not the imprint is false. Dom Connolly and Anne Dillon argue that 'Amsterdam' might have referred to Cardigan House, which housed the Confraternity. However, no other illicit Catholic work printed in London contained such grand frontispieces, indicating that this element at least must have been produced abroad. See Dom Hugh Connolly, 'The Benedictine Chapel of the Rosary in London (circa 1650-1681)', Downside Review, $5^{2}$ (1934), pp. 324-326. Anne Dillon also states that the 1657 edition of the book came from a secret press in Cardigan House, but she makes no indication whether this might have been the same for the 1663 edition: Dillon, 'The Benedictine Rosary Confraternity', p. 276.

19 Crowther and Vincent, Jesus, Maria, Joseph, dedicatory epistle.

20 Anna-Marie Linnell, 'Becoming a Stuart Queen Consort: Nuptial texts for Henrietta Maria of France and Catherine of Braganza, Queens of Britain', in Watanabe-O'Kelly and Morton (eds.), Queens Consort, p. 155; Nicolas Caussin, The holy court. Or the Christian institution of men of quality. With examples of those, who in court have flourished in sanctity. By Nicolas Caussin of the Society of Iesus. Written in French, \& translated into English by T.H. (Paris [St. Omer]: [English College Press], 1626), ETSC S1o7628, ustc 3012543.

21 Dillon, 'The Benedictine Rosary Confraternity', p. 284.

22 The method of saying the rosary of Our Blessed Lady. As it was ordered by Pope Pius the fifth, of the Holy Order of preachers. And as it is said in Her Majesties chappell at St. James. ([London]: s.n., 1669), ESTC R22O2O5. 
committee that had chosen the Benedictines for the queen's chapel. ${ }^{23}$ Whether or not Crowther and Vincent received their desired patronage is uncertain, but Catherine did possess a personal copy of the 1663 edition of Jesus, Maria, and Joseph, which she had bound with her coat of arms. ${ }^{24}$ This seems to indicate some degree of positive reception.

The pattern of authors calling for Catherine' protection in print persisted throughout her time as queen. In 1672, Thomas Godden, the queen's chaplain for the past decade, addressed the dedicatory epistle of his new pamphlet to the queen. ${ }^{25}$ He wrote:

Madame, The Book, before which I presume to fix Your Royal Name, being the Product of some Hours defalkt [sic] from Your Majesties Service, and the Subject of it Polemical, set me for some time at dispute with my self, whether I should let it venture to knock at Your Closet-Door [Due to her own practices] ... some Treatise of Divine Love ... would suit much better with that Better Part, which you have chosen with Mary, than a Book of Controversy. Here then my thoughts were at a stand, how to make my Address without Offence I must be guilty of a greater Trespass, should I doubt of obtaining either Your Pardon or Protection. ${ }^{26}$

In this passage, Godden invoked the queen's patronage and, more explicitly, a desire for her protection. The work for which Godden wanted her forgiveness and protection, entitled Catholicks no Idolaters, was a defence of Catholicism against the polemicist Edward Stillingfleet. ${ }^{27}$ Godden described his struggle in putting forth a controversy, recognising the queen's preference for internally-directed spiritual works. She herself was a devout religious reader, often 'retired most part of the day at her devotions and reading'. ${ }^{28}$ Charles II's acquisitions for the royal library often included devotional texts that would appeal to her. ${ }^{29}$ Godden made no attempt to obscure his identity, signing

23 David John Peter Baldwin, The Politico-Religious usage of the Queen's Chapel, 1623-1688 (University of Durham, Unpublished PhD Dissertation, 1999), p. 88.

24 Ushaw College Library, Ushaw IV.D.8.18.

25 Thomas Godden, Catholicks no idolaters, or, A full refutation of Doctor Stillingfleet's unjust charge of idolatry against the Church of Rome ([London]: s.n., 1672), EsTC R16817.

26 Godden, Catholicks, 'To the Queen', f. a2r-v.

27 Edward Stillingfleet, Discourse concerning the idolatry practiced in the Church of Rome, and the hazard of salvation in the communion of it. (London: Robert White, for Henry Mortlock, 1671), ESTC R28180.

28 Lady Tuke to Mary Evelyn, 2o March 1681[-2], British Library, Evelyn Ms ME6, quoted in Kim, 'Female Readers', p. 188.

29 Kim, 'Female Readers', pp. 191-192. 
the epistle with 'T.G'. However, outside of printed rebuttals, he faced no repercussions for his pamphlet. Unlike the rosarist handbook, Godden's work was printed in London, yet the wardens made no searches nor arrests. Instead, the work successfully circulated throughout London and beyond. ${ }^{30}$

Catherine's role as the foreign Catholic queen in England made her the default centre of Catholic culture and patronage in London. The dedications demonstrate that there was an expectation of both support and protection for new texts aimed at English Catholic audiences. The rest of this article will turn to two case studies in which illegal printing occurred within the queen's sphere of influence. The examination of these cases shows the extent to which Catherine took on this role, and what boundaries she was willing to cross in order to fulfill it.

\section{The Queen's Bookmen}

On 4 October 1669, the Stationers' Company recorded 'This day ... there were taken several Sheets of a Catholique Book from Winter the Printer. ${ }^{31}$ After arresting John Winter, the Stationers' Company wardens confiscated the sheets and 'partly demolished' one of his presses. ${ }^{32}$ However, before further action occurred, the Company received a warrant from Lord Howard, Almoner to Queen Catherine. In it, she testified that she had:

given and Granted Lycense and Authority to John Winter Printer in this Citty of London, to Print for her Majestys use; A Pious Book, Intituled, A Liturgical discourse of the holy Sacrafice of the Masse. ${ }^{33}$

Catherine followed up this declaration with a request 'that the said Winter might be Spared and not prosecuted', after which the Stationers' Company returned Winter's presses and damasked goods. ${ }^{34}$ The queen not only revealed that she had commissioned the book from Winter, but she also intervened to shield him from punishment.

The warrant also frames Catherine's, and thus Winter's, actions as legitimate. Despite her claim that she had granted him license for this work, no

30 The pamphlet was part of the library collection of the Jesuit community in Holbeck: see Hendrik Dijkgraaf, The Library of a Jesuit community at Holbeck, Nottinghamshire (1679) (Cambridge: LP Publications, 2003), p. 186.

$31 \quad C C L B T$, vol. I, 04.10.1669.

$32 \quad C C L B T$, vol. I, 04.10.1669.

33 CCLBT, vol. I, 15.10.1669.

$34 \quad C C L B T$, vol. I, 10.1.1670, 07.03.1670. 
formal license survives, nor did she have the ability to license texts. ${ }^{35}$ No text by that title was registered with the Stationers' Company. Moreover, both the content and the choice of printer make clear that the book was never intended to be printed legally and casts doubt on Catherine's assertion that she had 'ordered [Winter] to give public notice of this [warrant]', or at least that she had done so officially. ${ }^{36}$

Winter represented one of four unlicensed master printers operating in London. ${ }^{37} \mathrm{He}$ had obtained his own print-house through marriage in $1667 .^{38}$ The Licensing Act had attempted to regulate the print trade by requiring all printers and booksellers to register for a license with the Company of Stationers. It reinforced the limit of twenty master printers set by a Star Chamber decree in 1637 with a short list of exceptions. ${ }^{39}$ By remaining unlicensed, Winter not only thumbed his nose at the Company but also maneuvered with less oversight, albeit with a greater risk of searches. Unlicensed printers were ideal for illicit publications, and a master printer could produce such texts in larger numbers. If Catherine sought the book legitimately for her chapel, she would hardly have needed to employ Winter. Catherine, perhaps assisted by those around her, presumably chose Winter as the printer for the Liturgical Discourse for his resources and discretion.

The book in question, A Liturgical Discourse, was a new text by the Franciscan Richard Mason (religious name Angelus à Sancto) that related directly to the situation of English Catholics. ${ }^{40}$ While not overtly polemical, it promoted Catholicism over the Church of England, which rendered it seditious. Mason acted as chaplain to the Arundells of Wardour, a leading recusant gentry family that first served in the court of Henrietta Maria and then Catherine of Braganza. ${ }^{41}$ The book's first part and an abridgement thereof were printed secretly in London in 1670 and 1675 and contained dedications to Lord and

3514 Car. II. c. 33 , 2 .

$36 \quad$ CCLBT, 15.10.166o.

37 Michael Treadwell, 'Lists of Master Printers: The Size of the London Printing Trade, 16371723', in Robin Myers and Michael Harris (eds.), Aspects of Printing from 1600 (Oxford: Oxford Polytechnic Press, 1987), p. 159; CCLBT, vol. I, 07.10.1668.

38 Treadwell, 'Master Printers', p. 168, n. 19.

39 Treadwell, 'Master Printers', pp. 142-148.

40 Angelus à Sancto Francisco, A liturgical discourse of the holy sacrifice of the Mass. Wherein is contained a summary explication of the several parts, rites, and ceremonies thereof; out of the Scriptures, tradition, councils, and Holy Fathers: conformable to the use and practice of our Holy Mother the Church. The second part ([London]: s.n., 1669), Estc R32056.

41 J. Anthony Williams, 'Mason, Richard [name in religion Angelus à Sancto Francisco] (1599/16oo-1678), Franciscan friar', Oxford Dictionary of National Biography [hereafter $O D N B$ ] (Oxford: Oxford University Press, 2004), accessed 22 August 2017. 
Lady Arundell, respectively. ${ }^{42}$ Arundell had sought to propagate Catholicism in England and served as one of the key witnesses of the secret treaty of Dover, making him a strong ally and patron. ${ }^{43}$ Through her retainers the Arundells, the queen had patronage ties to the author. Either Mason or the Arundells might even have commissioned the printing of the specific texts. If that was the case, the queen's personal involvement in Winter's defense demonstrated an intent to protect those under her care.

Though Winter still endured some punishment, he escaped prosecution relatively unscathed. This must have been particularly vexing to the Stationers' Company, as October represented the third occasion within a year in which Winter had been found printing popish books. He received a fine in May for printing an unnamed popish book in large octavo, and in June the Company caught him printing sheets of $A$ journal of meditations for every day in the year. ${ }^{44}$ Composed by the Jesuit Nathaniel Bacon (alias Southwell), it had circulated as a Latin manuscript several decades earlier. In 1669, Edward Mico (alias Harvey), a fellow Jesuit, translated and expanded the book into English. ${ }^{45}$ Like the Liturgical Discourse, it represented a new work emerging from an English press for an English audience.

The queen had not interceded for the Journal of Meditations as she later did for the Liturgical Discourse. However, there is still a strong case to be made for Catherine's involvement in the production of the text. Winter had no other overt ties to the Catholic community, and he never faced accusations of popery - a catch-all indictment for anyone not sufficiently Protestant in the accuser's eyes. Moreover, with timing too exact to be coincidental, on the same day as the search of Winter's shop, the Company also investigated the premises of Theodore Sadler. This was the same Sadler who had served as Catherine's bookseller in 1662, when he provided books for her Chapel Royal at St James's Palace. Under interrogation, Sadler gave as his defense that he was 'Bookseller unto the Queens Majesty', indicating that he had continued in that position throughout the 166os. ${ }^{46}$ Thus two bookmen with independent but direct ties to the queen were investigated alongside one another. Indeed, during the

\footnotetext{
42 Angelus à Sancto Francisco, A liturgical discourse of the holy sacrifice of the Mass ... The first part ([London]: s.n., 1670), EsTC R32055; idem, A liturgical discourse ... abridged and accommodated to the pious use of devout Christians ([London]: s.n., 1675), ESTC R217659. Gabriel Glickman, 'Christian Reunion, the Anglo-French Alliance and the English Catholic Imagination, 166o-72', English Historical Review, 128 (2013), pp. 268, 280, 286.

$44 \quad$ CCLBT, vol. I, o8.o6.1669.

45 Thompson Cooper, 'Bacon, Nathaniel (1598-1676)', oDNB; Roger Baxter (ed.), Meditations for every day in the year (New York: Benzinger Brothers, 1884), p. 7 . 
investigation, Winter and Sadler's cases consistently appear together in the State Papers and Stationers' Company Records. ${ }^{47}$

Theodore Sadler's shop contained several popish books. The Company found nineteen copies of A devout method of hearing the mass (also referred to as The brief method).$^{48}$ They also found a work, likely in unbound sheets, called The passing bell of controversy, which Sadler claimed he only used as wallpaper and had never sold. ${ }^{49}$ Once more, the works were intended for an Englishspeaking Catholic audience. Sadler claimed he received the books from a Frenchman representing the superintendent of Somerset House, who denied this, hinting at an even wider network of overlapping Catholic patronage. ${ }^{50}$ If Sadler spoke the truth, his interview reveals the deep connections between Catherine's court and Somerset House. ${ }^{51}$

Despite the denial from Somerset House, the links between Theodore Sadler and both the queen consort and a Catholic residence not yet under her domain has various implications. In 1669, Henrietta Maria nominally possessed the royal residence, although she had not set foot in England since 1665 when she left for France, and would not do so again before her death in Colombes in September of 1669. ${ }^{52}$ The Queen Mother might have been absent, but Somerset House would still have been occupied by influential Catholics. Sadler demonstrates that the patronage networks of Somerset House and of Catherine of Braganza already overlapped two years before the queen took up residence.$^{53}$ In becoming consort, Catherine had taken on the mantle of being the centre of the various patronage networks.

47 SP 29/261 f.21, f. 4O; SP 29/45o f.129.

48 CCLBT, vol. I, 04.06.1669, o8.o6.1669; SP 29/261 f.21; A brief and devout method or manner of hearing masse. Wherein. [sic] are propounded, pious considerations on the most parts of the masse: much conduceing [sic] to the understanding thereof, and to raise affections correspondent to its mysteries. ([London]: s.n., 1669), ESTC R22566o.

SP 29/261 f.4O. The title likely refers to The passing-bell of controversy in point of religion, \&c. ([1650-1670]). An incomplete work containing this running title is held at Queen's College Library, Oxford: Upper Library 59.E.23. Not listed in ESTC.

$5^{\circ}$ SP 29/261 f.4O. The interpretation of the abbreviation as superintendent rather than superior comes from Henry Plomer, A Dictionary of the Printers and Booksellers who were at work in England, Scotland and Ireland from 1668 to 1625 (Oxford: Oxford University Press, 1922), p. 26 o.

51 Curiously, in the Stationer's Company warden's notes on the interview, he had originally written that the books came from St James before crossing it out and writing Somerset House, sP 29/261 f.40.

52 Miller, Popery and Politics, p. 20; Leech, 'Musicians in the Catholic Chapel', p. 572.

53 Henry Arundell also tied Catherine to Somerset House as he served as Henrietta Maria's Master of the Horse until her death. Peter Sherlock, 'Arundell, Henry, third Bardon Arundell of Wardour (bap. 16o8, d. 1694), ODNB. 
The prosecutions of Sadler and Winter indicate that Catherine actively fulfilled this role for all those who served the Catholic cause. The repercussions that Winter and Sadler faced initially appear as cases of textbook enforcement of the Licensing Act. Both men forfeited the seized works, which were then 'damasked'.54 However, the Licensing Act also empowered Justices of the Peace to 'to commit such Offenders to Prison' and inflict additional fines or punishments. ${ }^{55}$ Such punishments had been carried out against the unlicensed dissenting printer John Darby. ${ }^{56}$ Neither Sadler nor Winter faced prison for this instance involving in Catholic books, nor did they receive additional fines. Both the queen's intervention on behalf of Winter as well as Sadler's invoking of her name offered these bookmen a degree of protection. In contrast, the accused papist Robert Everard faced imprisonment for his attempt to have a piece on the situation in Ireland printed. ${ }^{57}$ Furthermore, both the Stationers' Company and Roger L'Estrange, surveyor of the press, had been attempting to seize Winter's workshop. ${ }^{58}$ That they did not do so after October should not be underestimated.

The Queen's intervention in Winter's case represents her most explicit attempt to protect a bookman in her employ. She leveraged her permission to supply her chapel against the laws that the Stationers' Company was tasked to enforce. For both Sadler and Winter, she was able to diminish the severity of the punishment faced for breaking the Licensing Act. However, the destruction of the physical books also points to the limits of her abilities. Despite her involvement, these books were not considered official commissions in the eyes of the Stationer's Company.

The $166 \mathrm{~g}$ incidents reveal the direct involvement of Catherine of Braganza in the illicit printing of Catholic books in London. It also highlights the larger network of Catholic patronage at work in London. These networks extended not only into the gentry, but also further into the London book trade. The cases of

5414 Car. II. c. 33, § 6; $C C L B T$, vol. I, o5.07.1669. The act of damasking, or defacing by stamping or marking, provided the Stationers' Company with a ready source of income. At this time, it did not represent an intense state-sponsored attempt to control the press as it would after the appointment by Bishop Compton in 1676. Rivington, The Records of the Worshipful Company of Stationers, pp. 33-35; Juliet Fleming, 'Damask Papers', in Andy Kesson and Emma Smith (eds.), The Elizabethan Top Ten:Defining Print Popularity in Early Modern England (London: Routledge, 2016), pp. 180-182.

5514 Car. II. c. $33, \S 13,15$.

$56 \quad C C L B T$, vol. I, 1666?, o9.07.1669; Walker, 'Censorship', pp. 226-227, 235. The severity of Danby's punishment derived from the greater threat perceived from dissenters in the 166os.

57 CCLBT, vol. I, 20.12.1668, o1.?.1669.

$5^{8}$ Treadwell, 'Master Printers', pp. 147-149; CCLBT, vol. I, o3.08.1668. 
Winter and Sadler represent an early attempt by Catherine to foster a domestic Catholic print network in London. As time progressed, these networks continued to grow around the person and household of the English queen.

\section{Somerset House Circles}

After 1670, Somerset House became Catherine's primary royal residence. Although she continued to live at the various palaces, her chapel and household all relocated to Somerset House. Catherine's inheritance of the palace after the death of Henrietta Maria strengthened her role as the primary arbiter of the direction of English Catholic culture. In the following years, Catholics also became more prominent at court. ${ }^{59}$ She reacted to these changes by taking firmer control of her own household and council. ${ }^{60}$ The changes occurring at Somerset House should be seen in connection with her own wishes and desires. This includes the role that Somerset House came to play in Catholic print culture.

Over the following decade, those involved in producing English Catholic books concentrated themselves around the revitalized and consolidated heart of Catholic London (see fig. 11.1). By the mid to late 1670s, multiple printers and booksellers, often with connections to each other, had set up shop within the neighbourhood of Somerset House. This placed the bookmen in the same area as other public and hidden sites of Catholicism, including Cardigan House and Weld House. ${ }^{61}$ The Portuguese, Spanish and French all used the latter as an ambassadorial residence at various times, and it possessed a Catholic chapel. Somerset, Cardigan and Weld Houses all had close connections with Catholic print culture and possessed many Catholic books. Cardigan House held the libraries of both the earl of Cardigan and Fr Thomas Vincent Sadler. ${ }^{62}$ Not only did Weld House contain the ambassadorial libraries, but at least one resident, the Carmelite William Joseph Travers, also engaged in the illicit printing of

59 Morton, 'Sanctity and Suspicion', p. 178; Corp, 'Catherine of Braganza', pp. 57-58. This included the replacement of Barbara Palmer with Louise de Kérouaille as Charles II's mistress and in 1673, the reveal of the Duke of York's conversion and his marriage to Mary of Modena.

6o Morton, 'Sanctity and Suspicion', p. 178.

61 Dillon, 'The Benedictine Rosary Confraternity'; 'Site of Weld House', in W. Edward Riley etc. (eds.), Survey of London (53 vols., London: London City Council, 1900-2020) v, pp. 93-97; Linda Levy Peck, Consuming Splendor: Society and Culture in Seventeenth-Century England (Cambridge: Cambridge University Press, 2005), pp. 230-232.

62 Connolly, 'The Benedictine Chapel', p. 323; Dillon, 'The Benedictine Rosary Confraternity', p. 276 . 

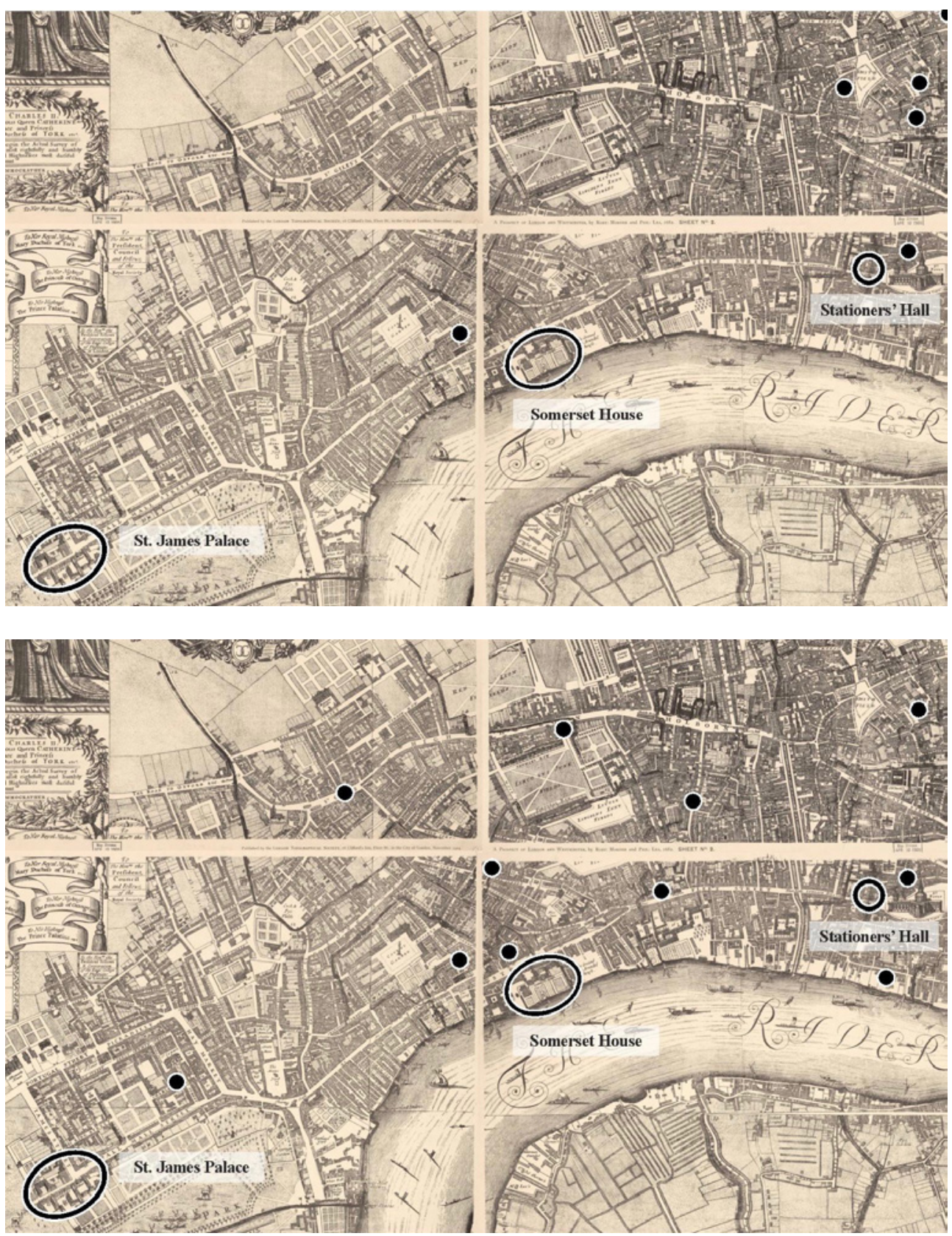

FIGURE 11.1 Map showing the location of printers and booksellers of Catholic texts in relation to Somerset House 1660-1670 (above) and 1670-1685 (below) when Catherine of Braganza controlled the royal residence as Consort. Stationer's Hall and St James' Palace are given as additional reference points. Inset of Morgan's Map of the Whole of London [London, 1682] (London: London Topographical Society, 1904) DIGITAL COPY, LIBRARY OF CONGRESS, GEOGRAPHY AND MAP DIVISION 
further Catholic material. ${ }^{63}$ However, by and large, Somerset House dominated in its ties to the illegal book trade.

Somerset House also became a frequent hiding place for banned texts. As Dorothy Kim describes, 'Catherine was covertly, and against the King's law, keeping contraband items at her private chapel. ${ }^{64}$ These were separate from the books Catherine had been permitted to order in 1662 when she had equipped her chapel. Travers himself hid books in the private room of the queen's confessor after receiving word that his library would be searched. ${ }^{65}$ The notorious Catholic bookseller Matthew Turner, his brother-in-law Moore, and another bookseller named Dod secreted away books in the stable loft in $1676 .^{66}$ These men had no official roles connecting them to the royal residence, yet they could access secure locations. Given the scrutiny applied to foreign and especially Catholic queens, Catherine's entourage would not have risked granting this permission without her consent. In the opening stages of the Popish Plot, Titus Oates again connected Turner and Moore to Somerset House and accused the latter of hiding £5oo worth of popish books at Somerset House. ${ }^{67}$ Oates could not prove these allegations, but his statements nevertheless demonstrate that the tradition of hiding books at the queen's residence, particularly by Turner and Moore, was an established one.

Somerset House served as more than a receptacle for seditious books. In 1676 . Catherine's involvement as a patron of illicit print again came to the fore with the arrest of her bookseller-in-ordinary, Anthony Lawrence. On 21 July, the Privy Council ordered that he be brought into custody for printing a Catholic book entitled The Great Sacrifice of the new Law. ${ }^{68}$ The Council deemed this book particularly dangerous because it provided a translation of the Roman Mass into English. The case surrounding The Great Sacrifice escalated when Lawrence produced a warrant for the work 'under the hand and seal' of Dom Francisco de Melo. ${ }^{69}$ De Melo served as Lord Chamberlain to the queen. Furthermore, he acted as the Portuguese ambassador to England from 1663 to 1667 and again from 1671 to his death in $1678 .{ }^{70}$ In brief, the Council had

63 Walter Joseph Travers, 'Autobiography of Father Bede of St. Simon Stock (Walter Joseph Travers)', in Benedict Zimmerman (ed.), Carmel in England: A History of the English Mission of the Discalced Carmelites, 1615 to 1849 (London: Burns \& Oates, 1899), pp. 241-246.

64 Kim, 'Female Readers', p. 189.

65 Kim, 'Female Readers', p. 244-255.

$66 \quad$ ссLBT, vol. II, 09.08.1676.

$67 \quad C C L B T$, vol. II, 11.01.1678.

$68 \quad C C L B T$, vol. II, 21.07.1676. Lawrence also acted as a printer and binder.

$69 \quad$ CCLBT, vol. II, 21.07.1676.

70 Susana Varela Flor, 'D. Francisco de Melo Manuel da Câmara: biografia, património, estatuto social e fidelidades (1626-1678)', Análise Social, 215 (2015), p. 36o. 
discovered that Catherine's lord chamberlain and ambassador to her home kingdom had commissioned her bookseller to print a seditious popish book.

De Melo's dual positions as lord chamberlain and ambassador allowed him a great deal of flexibility. When the Privy Council attempted to question him about his warrant for The Great Sacrifice, he responded that he could not answer without leave from his prince, the Portuguese king. ${ }^{71} \mathrm{He}$ thus manipulated his domestic and international roles to suit his objectives, which included the printing of Catholic books beyond The Great Sacrifice. A later deposition indicated that he 'caused several Popish Books to be Printed in English'. ${ }^{72} \mathrm{He}$ also had his own patronage ties. The author, a priest named James Dymock, was closely connected to de Melo, receiving from him both friendship and patronage. The priest even used the Portuguese embassy as a base to smuggle books and correspondence. ${ }^{73} \mathrm{He}$ expressed his gratitude towards de Melo by dedicating The Great Sacrifice to the ambassador.

On the surface, The Great Sacrifice centred around de Melo. He had the connection to the author, issued the warrant, and, as Catherine's Lord Chamberlain, would have known her bookseller. However, de Melo derived much of his power from his relationship to the queen. She provided his wages and on occasion even helped pay his debts. ${ }^{74} \mathrm{He}$ had formed part of her initial entourage in 1662, and they had affection for each other. ${ }^{75}$ They shared the same mission to foster English Catholicism. De Melo later faced a backlash for his role in the The Great Sacrifice scandal. The Portuguese king chastised the ambassador not for commissioning the publication, but rather for doing so too early, before the situation of Catholics was firmly secured..$^{76}$ As such, de Melo's actions and those of Catherine of Braganza should be viewed as intertwined. The absence of her name on the records does not exclude her involvement.

The dedication of The Great Sacrifice compared the translation done by the author to the work done by de Melo's embassy to care for the people, indicating that the book might have been intended in part for the Portuguese embassy chapel. ${ }^{77}$ In contrast, Edward Carpenter stated that the mass book

\footnotetext{
71 Shaw, The Anglo-Portuguese Alliance, p. 176.

72 Francisco de Faria, The examination of Francisco de Faria delivered at the bar of the House of Commons (Dublin: s.n., 168o), p. 2, ESTC R220211. 
was for Catherine's household. ${ }^{78}$ However, the print license provided by de Melo called for nine hundred copies: an improbably large number for the legitimate congregation of either chapel. Anthony Marevile, de Melo's secretary, claimed the warrant had been altered from the original one hundred copies. ${ }^{79}$ Even if he lied, Marevile's claim identified one hundred copies as the usual number suitable for a chapel - in which case, the figure of nine hundred certainly applied to a much larger population. If Marevile spoke the truth, then another member of the print network had seized upon the chance to increase the order. However, the reactions of the Privy Council to the text indicate that this book would never have been permitted, and that Marevile likely lied.

Catherine served as the focal point around which the illicit Catholic print trade organised itself. It would not have done so if there had been no encouragement or expectations from the queen. Her involvement with John Winter in 1669 proves that she did not just inherit these Catholic networks after she acquired Somerset House. Instead, her acquisition of her own private residence, staffed and filled with Catholics, changed the nature of the Catholic print networks already in place. Anthony Lawrence embodied the new patterns. He practiced Catholicism, operated in the geographical vicinity of Somerset House and worked alongside other Catholic bookmen. Lawrence was recorded as a recusant in 1674; Catherine's retention of him as her bookseller followed her developing pattern of hiring gentry and lay recusants to serve in her household. ${ }^{80}$ His bookshop was on Exeter Street, across the Strand from the queen's residence. ${ }^{81} \mathrm{He}$ was not the only one to follow this pattern, and though he was the only one formally employed by the queen, he also served as a gateway to the wider community.

Further explorations into Anthony Lawrence's trade connections reveal how deeply interwoven Catholic book networks had become. During questioning, Lawrence named another Catholic involved in the production and distribution of The Great Sacrifice: a Catholic publisher named James Thompson. ${ }^{82}$ A close neighbour of Lawrence's, the two men had collaborated previously on another

78 Edward Carpenter, The Protestant Bishop: Being the Life of Henry Compton, 1632-1713 Bishop of London (London: Longmans, Green and Co., 1956), p. 68.

79 Shaw, The Anglo-Portuguese Alliance, p. 176.

8o 'Middlesex Sessions Rolls: 1674', in John Cordy Jeaffreson (ed.), Middlesex County Records (London: Middlesex County Record Society, 1892), pp. 45-57; Shaw, 'The Anglo-Portuguese Alliance', p. 175; 'Establishment of Her Majesty Queen Catherine, Consort of King Charles II', in J. Cyril M. Weale (ed.), Registers of the Catholic Chapels Royal and of the Portuguese Embassy Chapel 1662-1829 (London: John Whitehead \& Son LTD, 1941), pp. xxix-xxxii.

81 Lawrence gave this address as well as his office as "book-seller in ordinary to Her Majesty" on the imprint for Nicole, The Grounds of Soveraignty; SP 29/383 f.245. CCLBT, vol. II, 04.08.1676. 
Catholic-authored text. ${ }^{83}$ Thompson had a history of dealing in Catholic books from at least ${ }^{1650} .^{84}$ This is likely the same Thompson described in a 1667 tract as boasting of having a shop in Somerset House where 'Popish Books and Popish Knacks are sold' ${ }^{85}$ If so, as with Theodore Sadler, the Catholic print networks connected with Catherine of Braganza and Henrietta Maria's households had many overlaps.

In a later 1678 investigation, Thompson had ties to the same Matthew Turner who hid books at Somerset House, as well as to another printer of Catholic works, Nathaniel Thompson. ${ }^{86}$ Later, when Catherine was Dowager Queen, Thompson and Turner printed and sold the sermons from her chapels. ${ }^{87}$ Turner had his own previous connection to the queen that connected her Somerset House circle to the networks she had developed in the 166os. Theodore Sadler had taken Turner on as his apprentice in 1663, a year after he began serving as the queen's bookseller. ${ }^{88}$ Turner, therefore, had been present for almost the entirety of Sadler's employment by Catherine. In 1673, he established his own book shop in Holborn, not far from Somerset House. ${ }^{89}$ For the rest of Charles II's reign and all of James II's, Turner was the most well-known popish bookseller. Neither James Thompson, Matthew Turner, nor Nathaniel Thompson had stated ties to the queen. None of these men served officially as her printers or booksellers, nor did she intervene overtly in any of their cases. Yet, in exploring the careers of the prolific contributors to the illicit Catholic book market, the story continuously turns to Somerset House and the figure of Catherine of Braganza.

Though these networks display a continuity throughout the Restoration, Catherine's ability to provide patronage fluctuated with the political situation.

83 Pierre Nicole, The Grounds of Soveraignty [sic] and Greatness (London: s.n., 1675), ESTC R228404.

84 Joannes Maria Blom, The Post-Tridentine English Primer (Unpublished PhD Dissertation, Radboud University, 1979), pp. 54-56.

85 House of Commons, Londons flames discovered by informations taken before the Committee, appointed to enquire after the burning of the city of London (London: s.n. 1667), p. 10, EsTC R923. The tract also names a William Tompson, but this seems to be a different person and not a bookseller. The only other bookman named Thompson, Nathaniel, always denied accusations of Catholicism.

$86 \quad C C L B T$, vol. II, 26.10.1678; ?.10.1678.

87 Two examples are $A$ sermon of judgement, preached before the Queen Dowager ... Published by her Majesties order (London: Nat[haniel] Thompson,1687), ETSC R8585; A sermon preached before her Majesty, the Queen Dowager ... (London: Matthew Turner, 1686), ESTC $\mathrm{R} 28856$.

886 April 1663, Records of London's Livery Companies Online (ROLLCO), https://www .londonroll.org/home., accessed 22 August, 2017.

89 Plomer, Dictionary of printers and booksellers, p. 294. 
At the onset of the Popish Plot, the Catholic print networks in London were widespread. Contemporaries saw both this and the role of Somerset House and the queen in the promotion and protection of these networks. As a result of the escalating panic over popery, in 168 o the queen closed up Somerset House and returned to her chapel at the more private St James' Palace. ${ }^{90}$ At the same time, royal proclamations and parliamentary acts banned Catholics (other than householders and tradesmen) from London, forbade any Englishman to attend the popish ambassadorial chapels and excluded 'papists' from the book trade. ${ }^{11}$ These decrees often proved to be unsuccessful; Turner, for instance, remained in business throughout the period. ${ }^{92}$

New patrons of Catholic print arose among the imprisoned lords Castlemaine, Arundel, and Powis, as well as their wives and the midwife Elizabeth Cellier. However, they authored not devotional but polemical pieces attacking the unlawful treatment of the Catholic lords and priests. ${ }^{93}$ Printing of devotional works likely continued, but the state fixed its attention on the new circles. Nevertheless, the transformation of Catherine and her household into the 'protagonists' of the Popish Plot forced her to withdraw in her role as patron to the city's Catholics. ${ }^{94}$ The forcible retreat of Catherine had altered the character of illicit Catholic printing in London. It would alter again in 1686, when James II's royal dispensations enabled the printing of hundreds of state licensed Catholic texts. Among those texts were several sermons and more 'published by her Majesties order. ${ }^{95}$ Catherine once more emerged as a promoter of Catholicism and print.

\section{Conclusion}

Catherine of Braganza represented one of the most visible consumers of Catholic print in Restoration England. She had the ability to legitimately order Catholic works, both for her library and to set up her chapel, as was outlined

$90 \quad$ Miller, Popery and Politics, p. 21; Simon Thurley, Somerset House: The Palace of England's Queens 1551-1692 (London: London Topographical Society, 2009), p. 72.

91 Miller, Popery and Politics, p. 163.

92 Miller, Popery and Politics, pp. 164-168.

93 The most famous of which were Elizabeth Cellier's Malice Defeated (London: Elizabeth Cellier, 1680), ESTC R203665, and Castlemaine's The compendium: or, A short view of the late tryals (London: s.n., 1679), ESTC R5075; Penny Richards, 'A Life in Writing: Elizabeth Cellier and Print Culture', Women's Writing, 7 (2000), pp. 411-425.

94 Morton, 'Sanctity and Suspicion', p. 19 o.

95 A sermon preached before her Majesty (1686); A sermon of judgement (1687); A sermon preach'd before Her Majesty (London: John and Thomas Lane, 1687), EstC R20868o. 
in her marriage contract. Yet, her greatest patronage of English Catholic print came not through approved orders for her chapel, but rather through support of illicit print. The seditious books that can be tied to Catherine or her household followed the pattern of focus on daily devotions and pastoral survival. These books were not just variations on the books that she ordered from Sadler in 1662. Several certainly could have been for her private reading and for those in her household, but they also fit the genre of works favoured by recusants. They instructed English Catholics on the performance of mass, recitation of the rosary and daily prayers and meditations. They continued a tradition of Catholic print in England from the sixteenth century, the attention fixed on maintenance of the existing Catholic community, especially when priests were unavailable. ${ }^{96}$ Catherine was among the few in England with guaranteed access to priests, so her support for these works above and beyond her own needs suggests that she intended to support and sustain a wider Catholic audience.

Catherine's involvement in illicit publication despite and beyond her own legal allowance of Catholic books demonstrated her intention to supply devotional aids to a larger audience. By looking at the king's consort and those in her circle, what emerges is the promotion of print banned by the same laws Charles tried to use to regulate the press. At least two of her booksellers repeatedly participated in the domestic printing of Catholic books, and more cases might have escaped detection. Furthermore, Catherine provided the salary of the Portuguese ambassador, who in turn overtly funded prohibited Catholic print using her own bookseller. After acquiring Somerset House, she could offer financial support, storage locations, and access to further consumption networks. She also wielded enough influence to intervene occasionally to protect those bookmen acting on her behalf, if not from initial arrest, then from further repercussions. As Charles II and Parliament sought to censor sedition against government and the Church of England, his queen subverted these laws to support English Catholics, fulfilling part of her role as a Catholic consort, at least as it was seen in the eyes of Catholic Europe.

96 Alexandra Walsham, "Domme Preachers"? Post-Reformation English Catholicism and the Culture of Print', Past and Present, 168:1 (2000), pp. 72-123. 